\title{
ANALISIS TATA KELOLA TEKNOLOGI INFORMASI MENGUNAKAN KERANGKA KERJA COBIT 4.1 PADA FAKULTAS TEKNIK UNDIP
}

\author{
Arini Arumana $^{1)}$, Adian Fatchur Rochim ${ }^{2)}$, Ike Pertiwi Windasari ${ }^{2)}$ \\ Program Studi Sistem Komputer, Fakultas Teknik, Universitas Diponegoro, \\ Jln. Prof. Sudharto, Tembalang, Semarang, Indonesia \\ park.arin@yahoo.co.id
}

\begin{abstract}
Abstrak - Peran teknologi informasi dalam suatu instansi sudah tidak dapat dielakkan lagi, mengingat perkembangannya yang begitu pesat seiring berjalannya waktu. Namun masalah yang sering terjadi di instansi adalah penggunaan teknologi informasi yang kadang tidak sesuai dengan harapan. Oleh karena itu diperlukan tata kelola terhadap penggunaan teknologi informasi yang biasa disebut dengan IT Governance. Fakultas teknik UNDIP adalah salah satu fakultas yang dalam operasionalnya sangat mengandalkan teknologi informasi, baik dalam aktifitas belajar mengajar maupun dalam menjalankan operasional bisnis. Kondisi sekarang di Fakultas Teknik sendiri tidak terdapat suatu indikator yang dapat menyatakan bahwa kinerja TI yang berjalan telah sesuai dengan visi dan misi Fakultas Teknik, oleh karena itu perlu dilakukan analisis tata kelola teknologi informasi, guna mengetahui performa TI sekarang sesuai dengan yang diharapkan oleh managemen atau tidak.

Hasil dari analisis ini berupa tingkat kematangan tata kelola TI yang mecerminkan kondisi tata kelola TI di Fakultas Teknik dengan mengacu pada maturity level yang disediakan kerangka kerja COBIT 4.1, yakni dari level 0 (non-existent) sampai 5 (optimized). Berdasarkan analisis yang dilakukan, secara garis besar kondisi kematangan tata kelola TI Fakultas Teknik berada pada level 2 yakni repeatable but intuitive. Kondisi ini mengacu pada beberapa kelemahan dalam proses-proses TI yang berjalan, diantaranya penetapan dan dokumentasi tindakan, kebijakan dan prosedur yang minim, serta tidak tersedianya service level yang disetujui bersama.
\end{abstract}

Kata Kunci : Tata Kelola TI, tingkat kematangan, COBIT 4.1

\section{Pendahuluan}

$\mathrm{I}$ NFORMASI dan teknologinya merupakan aset yang paling berharga dalam instansi atau organisasi, namun hal ini sering kali kurang dipahami. Instansi yang sukses mengetahui nilai lebih dari teknologi informasi dan menggunakannya untuk meningkatkan nilai instansi itu sendiri. Instansi juga harus memahami dan mengelola resiko terkait, seperti peningkatan pemenuhan akan peraturan atau regulasi dan ketergantungan proses bisnis terhadap teknologi informasi.

Seiring dengan perkembangan teknologi informasi yang semakin canggih, kebutuhan akan jaminan terhadap nilai dari teknologi informasi, pengelolaan resiko-resiko teknologi informasi dan kebutuhan akan kendali terhadap informasi, telah dipahami sebagai elemen kunci dalam tata kelola instansi atau organisasi. Instansi harus memenuhi kebutuhan akan informasi dalam hal kualitas, fiduciary (kepercayaan) dan keamanan. Pihak manajemen juga harus memperhatikan optimasi dari penggunaan sumberdaya teknologi informasi yang tersedia, termasuk didalamnya adalah aplikasi, informasi, infrastruktur dan manusia. Guna melaksanakan tanggungjawab tersebut, sekaligus guna mencapai tujuan instansi, manajemen harus mengerti kondisi teknologi informasi dari instansi dan memutuskan tata kelolanya apa yang harus dilakukan dan bagaimana pengendaliannya.

Fakultas Teknik UNDIP adalah salah satu fakultas yang dalam operasionalnya menggunakan teknologi informasi, seperti sistem informasi kepegawaian, sistem informasi eksekutif dan lain-lain, namun di Fakultas Teknik tidak terdapat suatu indikator yang dapat menyatakan bahwa kinerja teknologi informasi telah sesuai dengan tujuan yang ingin dicapai. Maka perlu dilakukan analisis tata kelola teknologi informasi guna mengetahui apakah performa teknologi informasi sekarang telah sesuai dengan yang diharapkan oleh manajemen atau tidak.

Sehubungan dengan alasan tersebut, diperlukan adanya sebuah mekanisme audit terhadap pengelolaan teknologi informasi (IT governance). Secara umum kerangka kerja tata kelola TI serta pengendalian yang dibutuhkan untuk mencapainya disediakan oleh COBIT (Control Objective for Information and related Technology). COBIT merupakan suatu kerangka kerja atau panduan standar praktik manajemen teknologi informasi. Praktik-praktik tersebut akan membantu mengoptimalkan investasi teknologi informasi, memastikan penyampaian layanan dan menghasilkan pengukuran dalam menentukan saat dimana terjadi kesalahan.

Tujuan dari tugas akhir ini adalah adalah melakukan pengukuran tingkat kematangan (maturity level) tata kelola teknologi informasi Fakultas Teknik UNDIP menggunakan kerangka kerja COBIT 4.1

\section{TINJAUAN PUSTAKA}

\section{A. Tata Kelola Teknologi Informasi}

Tata Kelola Teknologi Informasi (IT Governance) menurut ITGI (2007) adalah tanggung jawab dewan direktur dan manajemen eksekutif, yang terdiri atas kepemimpinan, struktur organisasi dan proses yang memastikan bahwa TI perusahaan mendukung dan memperluas strategi dan tujuan perusahaan.

Sanyoto Gondodiyoto (2007) menyatakan bahwa tata kelola TI merupakan salah satu bagian terpenting dari kesuksesan penerapan good corporate governance. IT Governance memastikan pengukuran efektifitas dan efisiensi 
peningkatan proses bisnis perusahaan melalui struktur yang terkait dengan TI menuju ke arah tujuan strategis perusahaan. Tata kelola TI (IT Governance) memadukan best practices proses perencanaan, pengelolaan, penerapan, pelaksanaan dan pengawasan kinerja untuk memastikan bahwa TI benar mendukung pencapaian perusahaan.

Menurut Weber (2000) terdapat berbagai alasan mengapa tata kelola diperlukan bagi sebuah perusahaan, diantaranya:

1. Kerugian akibat kehilangan data. Data merupakan asset yang sangat berharga bagi setiap perusahaan. Jika data hilang karena unsur kesengajaan ataupun tanpa kesengajaan akan mengakibatkan kerugian besar bagi perusahaan.

2. Kesalahan dalam pengambilan keputusan yang dibuat pihak manajemen bisa terbantu dengan adanya bantuan sistem TI. Misalnya penggunaan Decision Support System (DSS) sudah banyak diterapkan di perusahaan untuk membantu pihak manajemen dalam menentukan keputusan/ kebijakan yang harus dijalankan, sehingga keputusan tersebut akan menghasilkan kinerja yang lebih baik dari bagian TI.

3. Risiko kebocoran data. Pengolahan data yang baik akan mengurangi tingkat kebocoran data kepada pihak yang tidak memiliki kepentingan. Kebocoran data diperusahaan bisa diminimalkan dengan cara menerapkan sistem pengolahan dan dokumentasi data yang benar.

4. Penyalahgunaan komputer. Banyak orang pintar tetapi ada yang menggunakan kepintaran tersebut untuk mengganggu sistem TI pihak lain. Misalnya hacker atau cracker adalah contoh orang pintar yang menyalahgunakan komputer untuk mengganggu sistem pihak lain.

5. Kerugian akibat kesalahan proses perhitungan. Kesalahan perhitungan data biasanya terjadi saat terjadi perubahan sistem terkomputerisasi lama ke sistem yang baru. Sangat sulit untuk mengetahui kesalahan perhitungan data akibat pergantian sistem, kalaupun bisa akan membutuhkan waktu yang relatif lama.

6. Tingginya nilai investasi TI. Tatakelola TI yang tidak menerapkan perencanaan yang matang biasanya akan membutuhkan biaya yang besar dan kemungkinan manfaat yang didapat dari investasi tersebut tidak optimal.

\section{B. Kerangka Kerja COBIT}

COBIT (Control Objective for Information and Related Technology) merupakan a set of best practices (framework) bagi pengelolaan teknologi informasi (TI). COBIT disusun oleh The IT Governance Institute (ITGI) dan Information System Audit and Control Association (ISACA), tepatnya dulu disebut Information System Audit and Control Foundation (ISACF) pada tahun 1992.

COBIT membantu memenuhi berbagai kebutuhan manajemen dengan menjembatani gap antara resiko bisnis, kebutuhan kendali dan permasalahan teknis. COBIT memberikan panduan melalui sebuah doman dan framework proses serta menyajikan aktivitas dalam sebuah struktur logis dan terkelola. Kaidah penerapan COBIT dibentuk dari konsensus para pakar yang akan membantu dalam mengoptimalkan investasi informasi dan akan memberikan sebuah ukuran ketika terdapat sebuah kesalahan.

Jurnal Teknologi dan Sistem Komputer - Vol.2, No.2, April 2014
Aktivitas teknologi informasi pada COBIT 4.1 didefinisikan ke dalam empat domain yaitu Perencanaan dan Pengorganisasian / Plan and Organise (PO), Penyampaian Layanan dan Dukungan / Deliver and Support (DS), serta Pengadaan dan Implementasi / Acquire and Implement (AI), Monitor dan Evaluasi / Monitor and Evaluate (ME). Keempat domain tersebut saling berhubungan. PO menghasilkan arahan terhadap penyampaian solusi (AI) dan penyampaian layanan (DS). AI menghasilkan solusi dan membuatnya menjadi layanan. DS menerima solusi dan membuatnya dapat digunakan oleh user. ME memonitor semua proses untuk memastikan bahwa arahan yang ada telah dilaksanakan/diikuti.

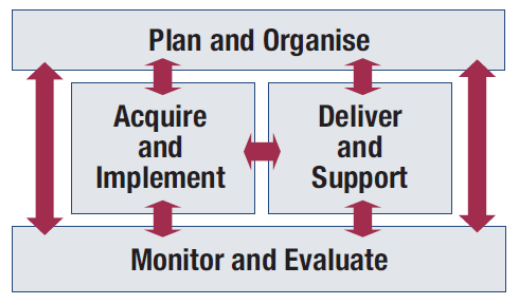

Gambar 1. Empat domain dalam COBIT

Dalam empat domain tersebut, terdapat 34 proses TI yang diidentifikasi oleh COBIT, yang dipakai secara umum. Proses-proses ini dapat digunakan untuk memastikan kelengkapan aktifitas dan tanggung jawab, namun tidak semua proses harus diaplikasikan, dapat pula di kombinasikan, tergantung pada keperluan perusahaan. COBIT juga mendefinisikan sasaran kendali untuk setiap 34 proses tersebut. Sasaran kendali TI (IT control objective) merupakan sekumpulan pernyataan atau syarat yang menjadi pertimbangan oleh manajemen untuk mendapatkan kontrol yang efektif terhadap setiap proses TI.

\section{Maturity Level COBIT}

Salah satu alat pengukuran dari kinerja suatu sistem teknologi informasi adalah model kematangan (maturity level) dari COBIT. Model kematangan untuk pengelolaan dan pengendalian pada proses teknologi informasi didasarkan pada metode evaluasi organisasi sehingga dapat mengevaluasi sendiri dari level tidak ada (0) hingga optimis (5). Model kematangan dimaksudkan untuk mengetahui keberadaan persoalan yang ada dan bagaimana menentukan prioritas peningkatan.

Pendefinisian model kematangan suatu proses teknologi informasi mengacu pada kerangka kerja COBIT secara umum adalah sebagai berikut (ITGI, 2007):

$>$ Level 0: non-exixtent. Sama sekali tidak ada proses TI yang diidentifikasi. Perusahaan belum menyadari adanya isu yang akan dibahas

$>$ Level 1: initial/ad-hoc. Terdapat bukti yang memperlihatkan perusahaan telah menyadari adanya isu yang perlu dibahas. Tidak ada proses yang baku, sebagai gantinya ada pendekatan khusus yang cenderung diterapkan per kasus. Pendekatan manajemen secara keseluruhan belum terorganisasi.

$>$ Level 2: repeatable but intuitive. Proses telah berkembang pada tahap dimana prosedur serupa diikuti oleh orang berbeda yang melakukan tugas yang sama. Tidak ada pelatihan dan komunikasi formal dari prosedur standar, dan tanggung jawab diserahkan kepada individu. Terdapat suatu kepercayaan yang tinggi terhadap 
pengetahuan dari individu, oleh karena itu kesalahan sering terjadi.

$>$ Level 3: defined process. Prosedur telah baku dan telah didokumentasikan, serta dikomunikasikan melalui pelatihan. Akan tetapi terserah kepada individu untuk mengikuti proses ini, oleh sebab itu penyimpangan akan sulit terdeteksi. Prosedur itu sendiri tidaklah rumit tetapi merupakan formalisasi dari kegiatan yang telah dilakukan.

$>$ Level 4: managed and measureable. Manajemen melakukan monitoring dan pengukuran kepatuhan terhadap prosedur dan pengambilan tindakan jika proses yang ada, nampak tidak bekerja secara efektif. Proses dikembangkan secara konstan dan memberikan good practice. Otomatisasi dan perangkat pembantu (tools) digunakan secara terbatas atau secara fragmentasi.

$>$ Level 5: optimized. Proses mencapai tingkatan bestpractice, sebagai hasil dari peningkatan terus-menerus dan maturity modeling dengan perusahaan lain. Teknologi informasi digunakan secara terintegrasi untuk mengotomatisasikan workflow, menyediakan perangkat pembantu untuk meningkatkan efektivitas dan mutu yang akan membuat perusahaan dapat dengan cepat menyesuaikan diri dengan perubahan.

\section{Profil Organisasi TI Fakultas Teknik UNDIP}

Organisasi TI di Fakultas Teknik adalah Tim SIFT (Sistem Informasi Fakultas Teknik) yang secara struktur dibawah bidang IV dalam menunjuk seorang koordinator. Dengan struktur organisasi berikut:

\section{Koordinator}

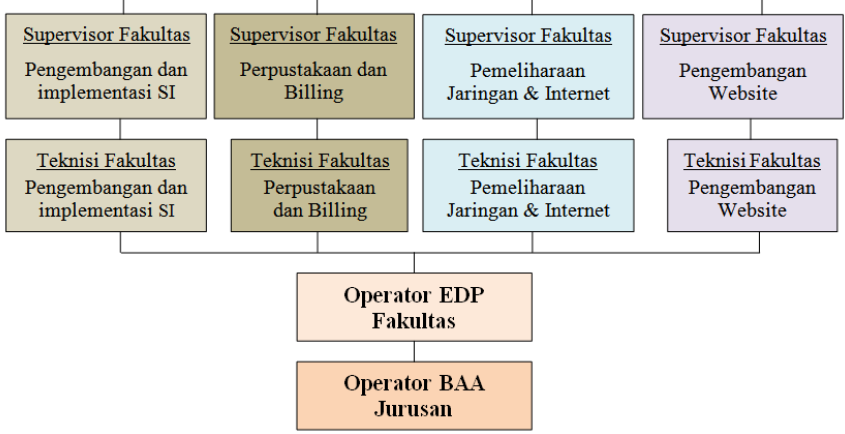

Gambar 2. Struktur organisasi SIFT

Program pendidikan yang diselenggarakan oleh Fakultas Teknik pada saat ini terdiri dari program Doktor (S3), program Magister (S2), program Sarjana (S1), program Diploma III dan Diploma IV kerjasama dengan Kementerian Pekerjaan Umum-UNDIP, yang sampai dengan Juli 2012 mempunyai sebanyak 11.497 mahasiswa dan sampai dengan Juli 2012, Fakultas Teknik UNDIP telah mempunyai alumni sebanyak 31.620 alumni. Fakultas Teknik juga memiliki bagian tata usaha dengan empat sub-bagian.

Fakultas Teknik mengoperasikan jaringan fiber optic yang menghubungkan Gedung Dekanat ke seluruh jurusan dan program studi yang ada di Fakulas Teknik, dan memiliki Empat perangkat server untuk mengoperasikan aplikasi berbasis WEB, antara lain Sistem Informasi Akademik, Perpustakaan on-line, Sistem Informasi Eksekutif dan Sistem Informasi

\section{Metode Penelitian}

Metodologi penelitian yang digunakan pada penelitian ini adalah metodologi kualitatif, yakni prosedur penelitian yang menghasilkan data deskriptif berupa kata-kata tertulis atau lisan dari orang-orang dan perilaku yang dapat diamati. Penelitian ini menggunakan studi kasus (objek), yaitu suatu cara yang sistematis dalam melihat suatu kejadian, mengumpulkan data, menganalisa informasi dan melaporkan hasilnya.

\section{A. Tahapan Penelitian}

Adapun tahapan penelitian ini digambarkan sebagai berikut:

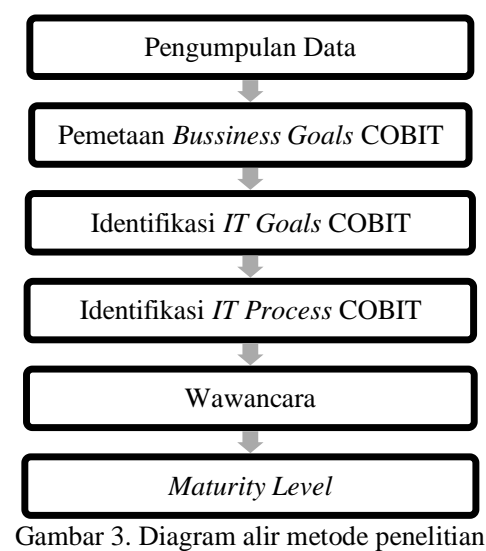

1. Pengumpulan Data

Pada tahap ini dilakukan pengumpulan data terkait dengan penelitian, baik melalui studi pustaka maupun observasi.

2. Pemetaan Bussiness Goals COBIT

Pada tahap ini dilakukan analisis tujuan bisnis dari Fakultas Teknik UNDIP yang telah ditetapkan dalam Rencana Strategis Fakultas Teknik UNDIP 2010-2015 untuk memperoleh gambaran kemana arah yang akan dituju. Kemudian tujuan bisnis tersebut disesuaikan dan dicari padanannya yang sesuai dengan COBIT 4.1.

3. Identifikasi IT Goals COBIT

Pada tahap ini dilakukan identifikasi dan analisa tujuan dari pengembangan teknologi infomasi COBIT berdasarkan tujuan bisnis instansi yang sebelumnya telah ditentukan. Tujuan Teknologi Informasi (IT Goals) didapatkan dengan cara pengaitan antara tujuan bisnis dengan tujuan teknologi informasi yang pemetaannya telah disediakan oleh COBIT.

4. Identifikasi IT Process COBIT

Pada tahap ini akan dilakukan identifikasi proses TI pada COBIT berdasarkan tujuan TI COBIT yang telah ditemukan sebelumnya.

5. Wawancara

Pada tahap ini dilakukan identifikasi maturity level untuk proses yang telah didapat dari tahap sebelumnya. Pertanyaan wawancara dibuat dari pernyataan-pernyataan yang ada di masing-masing level dari meturity level dari setiap proses TI yang ada.

6. Maturity Level

Tahap ini merupakan tahap pengukuran maturity level, sesuai dengan maturity model berdasarkan COBIT 4.1. Kondisi maturity level sendiri nantinya akan menggambarakan kondisi as-is dari instansi itu sendiri. 


\section{B. Metode Pengumpulan Data}

Metode pengumpulan data yang digunakan adalah sebagai berikut:

1. Studi kepustakaan

Penelitian ini dilakukan dengan cara mencari dan mengumpulkan data, sumber informasi dan bahan-bahan yang diperoleh dari buku, literatur, artikel terkait COBIT, IT Governance, metode penelitian yang digunakan, dan sebagainya.

2. Studi lapangan

Studi ini dilakukan dengan mendapatkan data secara langsung dari obyek penelitian. Data sekunder yang yang diambil merupakan data yang berupa Rencana Strategis, Laporan Keuangan Tahunan, dan lain- lain.

3. Wawancara

Metode wawancara adalah metode dengan melakukan tanya jawab dengan pihak yang terkait untuk mendapatkan informasi dan data-data yang dibutuhkan. Untuk tingkat kematangan (maturity level), penulis menggunakan pertanyaan tertutup, dimana penulis membatasi responden untuk menjawab dengan ya/tidak, dengan sumber pertanyaan berdasarkan COBIT 4.1. Hal ini dilakukan demi memusatkan pertanyaan agar lebih fokus pada penilaian kinerja serta tidak terlalu luas.

4. Observasi

Observasi adalah kegiatan melakukan pengamatan secara langsung pada lingkungan serta pengelolaan teknologi informasi pada instansi.

\section{Sampel Penelitian}

Narasumber wawancara dalam penelitian ini diantaranya adalah :

1. Ir. Sudjadi, MT (Koordinator)

2. Adian Fatchur R, ST, MT (Ka. bidang pemeliharaan jaringan dan internet)

3. Ir. Kodrat Imam Satoto, MT (Ka. bidang pengembangan dan implementasi SI)

4. Dr. Istadi, ST, MT (Ka. bidang pengembangan Website)

5. Ir. Yuli Christyono, MT (Ka. bidang perpustakaan dan billing)

6. Indah Wulani, A.Md (Operator EDP Fakultas)

Divisi di SIFT masih belum memiliki susunan yang lengkap secara struktural seperti yang ditentukan oleh COBIT, oleh karena itu dilakukan penyesuaian dengan kondisi lapangan. Secara umum, pembagian narasumber sebagai berikut:

- Pertanyaan umum yang terdapat di draft dapat ditujukan kepada koordinator.

- Divisi pengembangan dan implementasi SI, divisi perpustakaan dan billing, dan divisi pengembangan website merujuk pada pertanyaan mengenai keadaan dan pengelolaan sistem informasi.

- Pertanyaan mengenai perencanaan dan infrastruktur ditujukan kepada divisi pemeliharaan jaringan dan internet.

- Sedangkan mengenai pertanyaan yang terkait administrasi organisasi, yang tidak masuk dalam draft maturity level, melainkan mengenai administrasi, ditujukan kepada Indah selaku petugas EDP SIFT.

\section{ANALisis dan Pembahasan}

\section{A. Pemetaan Bussiness Goals COBIT 4.1}

Hal yang pertama kali dilakukan pada tahap ini adalah mengidentifikasi tujuan bisnis dan sasaran Fakultas Teknik UNDIP, yaitu:

1) Peningkatan mutu pembelajaran sehingga diakui secara internasional, dari segi kurikulum dan akreditasi program studi/ jurusan.

2) Peningkatan iklim penelitian dan pengabdian masyarakat serta publikasi internasional.

3) Peningkatan kualitas sumber daya manusia di Fakultas Teknik.

4) Peningkatan sarana dan prasarana yang efisien dan efektif.

5) Peningkatan kegiatan kerjasama yang terintegrasi dengan baik.

6) Mewujudkan penyelenggaraan keuangan dan sistem pengelolaan yang transparan, terdokumentasi dengan baik dan dapat dipertanggungjawabkan.

7) Terciptanya organisasi dan sistem manajemen internal yang komitmen, konsisten, bertanggung jawab, profesional, dan berdedikasi tinggi.

Setelah dirumuskan tujuan dan sasaran bisnis dari perusahaan selanjutnya akan dilakukan pemetaan dari tujuan dan sasaran bisnis tersebut dengan business goals COBIT 4.1. Berikut adalah tabel Business goal COBIT.

Tabel 1. Business goal COBIT 4.1

\begin{tabular}{|c|c|c|}
\hline \multirow[t]{3}{*}{$\begin{array}{l}\text { Financial } \\
\text { Perspective }\end{array}$} & 1 & $\begin{array}{l}\text { Provide a good return of investment of IT- } \\
\text { enabled business investment } \\
\text { (Menghasilkan ROI yang baik dari investasi } \\
\text { bisnis pada TI) }\end{array}$ \\
\hline & 2 & $\begin{array}{l}\text { Manage IT-related business risk } \\
\text { (Mengelola resiko bisnis yang berhubungan } \\
\text { dengan TI) }\end{array}$ \\
\hline & 3 & $\begin{array}{l}\text { Improve corporate governance and } \\
\text { transparency } \\
\text { (Meningkatkan tata kelola dan transparansi } \\
\text { perusahaan) }\end{array}$ \\
\hline \multirow[t]{6}{*}{$\begin{array}{l}\text { Customer } \\
\text { Perspective }\end{array}$} & 4 & $\begin{array}{l}\text { Improve customer orientation and service } \\
\text { (Meningkatkan orientasi dan layanan } \\
\text { pelanggan) }\end{array}$ \\
\hline & 5 & $\begin{array}{l}\text { Offer competitive product and service } \\
\text { (Menawarkan produk dan layanan yang } \\
\text { kompetitif) }\end{array}$ \\
\hline & 6 & $\begin{array}{l}\text { Establish service continuity and availability } \\
\text { (Menghadirkan keberlanjutan dan } \\
\text { ketersediaan layanan) }\end{array}$ \\
\hline & 7 & $\begin{array}{l}\text { Create agility in responding to changing } \\
\text { business requirements } \\
\text { (Menciptakan ketangkasan dalam memberi } \\
\text { tanggapan terhadap perubahan kebutuhan } \\
\text { bisnis) }\end{array}$ \\
\hline & 8 & $\begin{array}{l}\text { Achieve cost optimisation of service delivery } \\
\text { (Mencapai optimasi biaya dalam } \\
\text { penyampaian layanan) }\end{array}$ \\
\hline & 9 & $\begin{array}{l}\text { Obtain reliable and useful information for } \\
\text { strategic decision making } \\
\text { (Memperoleh informasi yang dapat } \\
\text { diandalkan dan berguna, untuk pengambilan } \\
\text { keputusan strategis) }\end{array}$ \\
\hline \multirow[t]{2}{*}{$\begin{array}{l}\text { Internal } \\
\text { Perspective }\end{array}$} & 10 & $\begin{array}{l}\text { Improve and maintain business process } \\
\text { functionality } \\
\text { (Meningkatkan dan menjaga kebergunaan } \\
\text { proses bisnis) }\end{array}$ \\
\hline & 11 & Lower process cost \\
\hline
\end{tabular}




\begin{tabular}{|l|c|l|}
\hline \multirow{1}{*}{} & 12 & $\begin{array}{l}\text { (Memperkecil biaya proses) } \\
\text { Provide compliance with external laws, } \\
\text { regulation and contracts } \\
\text { (Menghasilkan kesesuaian terhadap hukum } \\
\text { eksternal, peraturan dan kontrak) }\end{array}$ \\
\cline { 2 - 3 } & 13 & $\begin{array}{l}\text { Provide compliance with internal policy } \\
\text { (Menghasilkan kesesuaian terhadap } \\
\text { kebijakan internal) }\end{array}$ \\
\cline { 2 - 3 } & 14 & $\begin{array}{l}\text { Manage business change } \\
\text { (Mengelola perubahan bisnis) }\end{array}$ \\
\cline { 2 - 3 } $\begin{array}{l}\text { Learning } \\
\text { and growth } \\
\text { Perspective }\end{array}$ & 15 & $\begin{array}{l}\text { Improve and maintain operational and staff } \\
\text { productivity } \\
\text { (Meningkatkan dan mengelola produktifitas } \\
\text { operasional dan pegawai) }\end{array}$ \\
\cline { 2 - 3 } & 17 & $\begin{array}{l}\text { Manage product and business innovation } \\
\text { (Mengelola inovasi produk dan bisnis) }\end{array}$ \\
\hline $\begin{array}{l}\text { Acquire and maintain skilled and motivated } \\
\text { people } \\
\text { (Memperoleh dan menjaga (memelihara) } \\
\text { orang-orang yang terampil dan memiliki } \\
\text { motivasi) }\end{array}$ \\
\hline
\end{tabular}

Pemetaan tujuan dan sasaran bisnis FT UNDIP yang sesuai dengan business goals COBIT 4.1 diatas dapat dilihat pada tabel berikut:

Tabel 2. Pemetaan tujuan dan sasaran bisnis FT UNDIP dengan business goals COBIT 4.1

\begin{tabular}{|l|l|l|}
\hline No. & Sasaran FT UNDIP & $\begin{array}{l}\text { COBIT } \\
\text { business } \\
\text { goals }\end{array}$ \\
\hline 1. & $\begin{array}{l}\text { Peningkatan mutu pembelajaran sehingga } \\
\text { diakui secara internasional, dari segi } \\
\text { kurikulum dan akreditasi program studi/ } \\
\text { jurusan }\end{array}$ & $5,10,12,16$ \\
\hline 2. & $\begin{array}{l}\text { Peningkatan iklim penelitian dan pengabdian } \\
\text { masyarakat serta publikasi internasional }\end{array}$ & 6,17 \\
\hline 3. & $\begin{array}{l}\text { Peningkatan kualitas Sumber Daya Manusia } \\
\text { di Fakultas Teknik }\end{array}$ & 15,17 \\
\hline 4. & $\begin{array}{l}\text { Peningkatan sarana dan prasarana yang } \\
\text { efisien dan efektif }\end{array}$ & 4,6 \\
\hline 5. & $\begin{array}{l}\text { Peningkatan kegiatan kerjasama yang } \\
\text { terintegrasi dengan baik }\end{array}$ & 5 \\
\hline 6. & $\begin{array}{l}\text { Mewujudkan penyelenggaraan keuangan dan } \\
\text { sistem pengelolaan yang transparan, } \\
\text { terdokumentasi dengan baik dan dapat } \\
\text { dipertanggung jawabkan }\end{array}$ & 3,6 \\
\hline 7. & $\begin{array}{l}\text { Terciptanya organisasi dan sistem } \\
\text { manajemen internal yang komitmen, } \\
\text { konsisten, bertanggung jawab, profesional, } \\
\text { dan berdedikasi tinggi }\end{array}$ & 3 \\
\hline
\end{tabular}

Dari pemetaan diatas, dihasilkan Business Goal COBIT yang digunakan adalah:

- 3 (Improve corporate governance and transparency / meningkatkan tata kelola dan tranparansi perusahaan)

- 4 (Improve customer orientation and service / Meningkatkan orientasi dan layanan pelanggan)

- 5 (Offer competitive product and service / Menawarkan produk dan layanan yang kompetitif)

- 6 (Establish service continuity and availability / Menghadirkan keberlanjutan dan ketersediaan layanan)

- 10 (Improve and maintain business process functionality / Meningkatkan dan menjaga kebergunaan proses bisnis)

- 12 (Provide compliance with external laws, regulation and contracts / Menghasilkan kesesuaian terhadap hukum eksternal, regulasi dan kontrak)
- 15(Improve and maintain operational and staff productivity / Meningkatkan dan mengelola produktifitas operasional dan pegawai)

- 16 (Manage product and business innovation / Mengelola inovasi produk dan bisnis)

- 17 (Acquire and maintain skilled and motivated people / Memperoleh dan mengelola orang-orang yang terampil dan memiliki motivasi)

\section{B. Identifikasi IT Goals COBIT 4.1}

Setelah mengidentifikasi business goals langkah selanjutnya adalah mengidentifikasi IT goals yang sesuai dengan studi kasus. COBIT sendiri sudah memetakan business goals dengan IT goals, dan dari pemetaan itu dapat terlihat IT goals apa saja yang nantinya akan menunjang business goals perusahaan. Berikut adalah IT goals yang merupakan hasil dari pemetaan business goals yang sudah didapat ke dalam IT goals COBIT 4.1.

Tabel 3. Hasil pemetaan business goals ke IT goals COBIT 4.1

\begin{tabular}{|c|c|}
\hline No. & IT Goals \\
\hline 2 & $\begin{array}{l}\text { Respond to business requirements in line with board } \\
\text { direction. } \\
\text { (Menanggapi kebutuhan bisnis sejalan dengan arahan } \\
\text { dewan/direksi) }\end{array}$ \\
\hline 3 & $\begin{array}{l}\text { Ensure satisfaction of end users with service offerings and } \\
\text { service levels. } \\
\text { (Memastikan kepuasan pengguna terhadap layanan yang } \\
\text { ditawarkan dan tingkat layanan) }\end{array}$ \\
\hline 5 & $\begin{array}{l}\text { Create IT agility. } \\
\text { (Menciptakan ketangguhan TI) }\end{array}$ \\
\hline 6 & $\begin{array}{l}\text { Define how business functional and control requirements } \\
\text { are translated in effective and efficient automated solutions. } \\
\text { (Mendefinisikan bagaimana fungsional bisnis dan } \\
\text { kebutuhan kendali dijalankankan dalam solusi mandiri yang } \\
\text { efektif dan efisien) }\end{array}$ \\
\hline 7 & $\begin{array}{l}\text { Acquire and maintain integrated and standardised } \\
\text { application systems. } \\
\text { (Memperoleh dan mengelola sistem aplikasi yang } \\
\text { terintegrasi dan terstandarisasi) }\end{array}$ \\
\hline 8 & $\begin{array}{l}\text { Acquire and maintain an integrated and standardised IT } \\
\text { infrastructure. } \\
\text { (Memperoleh dan mengelola infrastruktur TI yang } \\
\text { terintegrasi dan terstandarisasi) }\end{array}$ \\
\hline 9 & $\begin{array}{l}\text { Acquire and maintain IT skills that respond to the IT } \\
\text { strategy. } \\
\text { (Memperoleh dan mengelola keterampilan TI guna } \\
\text { menanggapi strategi TI) }\end{array}$ \\
\hline 10 & $\begin{array}{l}\text { Ensure mutual satisfaction of third-party relationships. } \\
\text { (Memastikan kepuasan mutual dalam hubungan dengan } \\
\text { pihak ketiga) }\end{array}$ \\
\hline 11 & $\begin{array}{l}\text { Seamlessly integrate applications and technology solutions } \\
\text { into business processes. } \\
\text { (mengintegrasikan aplikasi dan solusi teknologi kedalam } \\
\text { proses bisnis tanpa henti) }\end{array}$ \\
\hline 13 & $\begin{array}{l}\text { Ensure proper use and performance of the applications and } \\
\text { technology solutions. } \\
\text { (Memastikan penggunaan dan performa yang layak dari } \\
\text { solusi teknologi dan aplikasi) }\end{array}$ \\
\hline 16 & $\begin{array}{l}\text { Reduce solution and service delivery defects and rework. } \\
\text { (Mengurangi cacat dan pengerjaan ulang dari penyampaian } \\
\text { layanan dan solusi) }\end{array}$ \\
\hline 18 & $\begin{array}{l}\text { Establish clarity of business impact of risks to IT objectives } \\
\text { and resources. } \\
\text { (Memastikan kejelasan pengaruh bisnis dari resiko terhadap } \\
\text { tujuan dan sumberdaya TI) }\end{array}$ \\
\hline 19 & Ensure critical and confidential information is withheld \\
\hline
\end{tabular}

JTSiskom - 166 


\begin{tabular}{|c|c|}
\hline & $\begin{array}{l}\text { from those who should not have access to it. } \\
\text { (Memastikan informasi yang penting dan rahasia aman dari } \\
\text { pihak yang tidak seharusnya mengakses) }\end{array}$ \\
\hline 20 & $\begin{array}{l}\text { Ensure automated business transactions and information } \\
\text { exchanges can be trusted. } \\
\text { (Memastikan bahwa transaksi bisnis terotomatisasi dan } \\
\text { perpindahan data dapat dipercaya) }\end{array}$ \\
\hline 21 & $\begin{array}{l}\text { Ensure IT services and the IT infrastructure can properly } \\
\text { resist and recover from failures due to error, deliberate } \\
\text { attack or disaster. } \\
\text { (Memastikan layanan TI dan infrastruktur TI dapat tahan } \\
\text { dan pulih dari kegagalan yang disebabkan oleh kesalahan, } \\
\text { serangan yang disengaja maupun bencana alam) }\end{array}$ \\
\hline 22 & $\begin{array}{l}\text { Ensure minimum business impact in the event of an IT } \\
\text { service disruption or change. } \\
\text { (Memastikan pengaruh minimal terhadap bisnis saat terjadi } \\
\text { gangguan layanan TI atau perubahan TI) }\end{array}$ \\
\hline 23 & $\begin{array}{l}\text { Make sure that IT services are available as required. } \\
\text { (Memastikan bahwa layanan TI tersedia sebagaimana } \\
\text { dibutuhkan/diminta) }\end{array}$ \\
\hline 24 & $\begin{array}{l}\text { Improve IT's cost-efficiency and its contribution to business } \\
\text { profitability. } \\
\text { (Meningkatkan efisiensi biaya TI dan kontribusinya } \\
\text { terhadap keuntungan bisnis) }\end{array}$ \\
\hline 25 & $\begin{array}{l}\text { Deliver projects on time and on budget, meeting quality } \\
\text { standards. } \\
\text { (Menyampaikan proyek tepat waktu dan tepat anggaran, } \\
\text { sesuai standar mutu) }\end{array}$ \\
\hline 26 & $\begin{array}{l}\text { Maintain the integrity of information and processing } \\
\text { infrastructure. } \\
\text { (Mengelola integritas informasi dan infrastruktur proses) }\end{array}$ \\
\hline 27 & $\begin{array}{l}\text { Ensure IT compliance with laws, regulations and contracts. } \\
\text { (Memastikan kepatuhan TI terhadap hukum, regulasi dan } \\
\text { perjanjian) }\end{array}$ \\
\hline 28 & $\begin{array}{l}\text { Ensure that IT demonstrates cost-efficient service quality, } \\
\text { continuous improvement and readiness for future change. } \\
\text { (Memastikan bahwa TI menampilkan kualitas layanan yang } \\
\text { efisien-biaya, peningkatan berkelanjutan dan kesiapan untuk } \\
\text { perubahan masadepan) }\end{array}$ \\
\hline
\end{tabular}

\section{Identifikasi IT Process COBIT 4.1}

Tahapan selanjutnya adalah penetapan IT process yang sesuai dengan IT goals yang sudah terpilih. Berikut adalah hasil dari IT process yang telah diidentifikasi berdasarkan IT goals:

Tabel 4. Daftar Hasil IT process COBIT 4.1

\begin{tabular}{|l|l|l|}
\hline No. & \multicolumn{2}{|c|}{ IT process } \\
\hline 1 & PO2 & $\begin{array}{l}\text { Define the information architecture } \\
\text { (Mendefinisikan arsitektur informasi) }\end{array}$ \\
\hline 2 & PO3 & $\begin{array}{l}\text { Determine technological direction } \\
\text { (Menetapkan tujuan teknologi) }\end{array}$ \\
\hline 3 & PO4 & $\begin{array}{l}\text { Define the IT processes, } \text { organisation and } \\
\text { relationships } \\
\text { (Mendefinisikan proses-proses TI, organisasi dan } \\
\text { hubungan) }\end{array}$ \\
\hline 4 & PO5 & $\begin{array}{l}\text { Manage the IT investment } \\
\text { (Mengelola investasi TI) }\end{array}$ \\
\hline 5 & PO6 & $\begin{array}{l}\text { Communicate management aims and direction } \\
\text { Mengkomunikasikan tujuan dan arahan } \\
\text { manajemen) }\end{array}$ \\
\hline 7 & PO8 & $\begin{array}{l}\text { Manage IT Human resources } \\
\text { (Mengelola sumberdaya manusia TI) }\end{array}$ \\
\hline 8 & PO10 & $\begin{array}{l}\text { Manage quality } \\
\text { Mengelola kualitas) }\end{array}$ \\
\hline 9 & AI2 & $\begin{array}{l}\text { Acquire and maints } \\
\text { (Memperoleh dan memelihara aplikasi perangkat }\end{array}$ \\
\hline
\end{tabular}

Jurnal Teknologi dan Sistem Komputer - Vol.2, No.2, April 2014

\begin{tabular}{|c|c|c|}
\hline & & lunak) \\
\hline 10 & $\mathrm{AI} 3$ & $\begin{array}{l}\text { Acquire and maintain technology infrastructure } \\
\text { (Memperoleh dan memelihara infrastruktur } \\
\text { teknologi) }\end{array}$ \\
\hline 11 & AI4 & $\begin{array}{l}\text { Enable operation and use } \\
\text { (Memungkinkan pengoperasian dan penggunaan) }\end{array}$ \\
\hline 12 & AI5 & $\begin{array}{l}\text { Procure IT resources } \\
\text { (Memperoleh/mendapatkan sumberdaya TI) }\end{array}$ \\
\hline 13 & AI6 & $\begin{array}{l}\text { Manage changes } \\
\text { (Mengelola perubahan) }\end{array}$ \\
\hline 14 & AI7 & $\begin{array}{l}\text { Install and accredit solutions and changes } \\
\text { (Menerapkan dan mengakui solusi dan } \\
\text { perubahan) }\end{array}$ \\
\hline 15 & DS1 & $\begin{array}{l}\text { Define and manage service levels } \\
\text { (Mendefinisikan dan mengelola tingkat layanan) }\end{array}$ \\
\hline 16 & DS2 & $\begin{array}{l}\text { Manage third-party services } \\
\text { (Mengelola layanan pihak ketiga) }\end{array}$ \\
\hline 17 & DS3 & $\begin{array}{l}\text { Manage performance and capacity } \\
\text { (Mengelola kinerja dan kapasitas) }\end{array}$ \\
\hline 18 & DS4 & $\begin{array}{l}\text { Ensure continuous service } \\
\text { (Memastikan layanan yang terus-menerus) }\end{array}$ \\
\hline 19 & DS5 & $\begin{array}{l}\text { Ensure systems security } \\
\text { (Memastikan keamanan sistem) }\end{array}$ \\
\hline 20 & DS6 & $\begin{array}{l}\text { Identify and allocate costs } \\
\text { (Identifikasi dan alokasi biaya) }\end{array}$ \\
\hline 21 & DS7 & $\begin{array}{l}\text { Educate and train users } \\
\text { (Mendidik dan melatih pengguna) }\end{array}$ \\
\hline 22 & DS8 & $\begin{array}{l}\text { Manage service desk and incidents } \\
\text { (Mengelola bagian pelayanan dan insiden) }\end{array}$ \\
\hline 23 & DS10 & $\begin{array}{l}\text { Manage problems } \\
\text { (Mengelola masalah) }\end{array}$ \\
\hline 24 & DS11 & $\begin{array}{l}\text { Manage data } \\
\text { (Mengelola data) }\end{array}$ \\
\hline 25 & DS12 & $\begin{array}{l}\text { Manage the physical environment } \\
\text { (Mengelola lingkungan fisik) }\end{array}$ \\
\hline 26 & DS13 & $\begin{array}{l}\text { Manage operations } \\
\text { (Mengelola operasi) }\end{array}$ \\
\hline 27 & ME1 & $\begin{array}{l}\text { Monitor and evaluate IT performance } \\
\text { (Mengawasi dan mengevaluasi kinerja TI) }\end{array}$ \\
\hline 28 & ME2 & $\begin{array}{l}\text { Monitor and Evaluate Internal Control } \\
\text { (Mengawasi dan mengevaluasi kontrol internal) }\end{array}$ \\
\hline 29 & ME4 & $\begin{array}{l}\text { Provide IT governance } \\
\text { (Mengadakan tata kelola TI) }\end{array}$ \\
\hline
\end{tabular}

\section{Klasifikasi Proses TI COBIT 4.1 ke Narasumber}

Klasifikasi narasumber dilakukan berdasarkan peran yang telah ditentukan COBIT 4.1 dalam diagram RACI (Responsible, Accountable, Consulted and/or Informed) pada setiap proses TI. Berikut merupakan hasil pemetaan setiap proses TI kepada narasumber secara spesifik dengan mengacu pada tanggung jawab yang dipetakan pada diagram RACI COBIT 4.1.

Tabel 5. Pemetaan proses TI ke narasumber

\begin{tabular}{|c|l|c|c|c|c|c|}
\hline No. & Proses & Sudjadi & Adian & Kodrat & Istadi & Yuli \\
\hline 1. & PO2 & $\bullet$ & $\bullet$ & $\bullet$ & $\bullet$ & $\bullet$ \\
\hline 2. & PO3 & $\bullet$ & $\bullet$ & & $\bullet$ & \\
\hline 3. & PO4 & $\bullet$ & $\bullet$ & & $\bullet$ & \\
\hline 4. & PO5 & $\bullet$ & & & & \\
\hline 5. & PO6 & $\bullet$ & & & & \\
\hline 6. & PO7 & $\bullet$ & $\bullet$ & $\bullet$ & $\bullet$ & $\bullet$ \\
\hline 7. & PO8 & $\bullet$ & & & & \\
\hline 8. & PO10 & $\bullet$ & & & & \\
\hline 9. & AI2 & & & $\bullet$ & & $\bullet$ \\
\hline 10. & AI3 & $\bullet$ & $\bullet$ & & $\bullet$ & \\
\hline 11. & AI4 & & $\bullet$ & & $\bullet$ & $\bullet$ \\
\hline 12. & AI5 & $\bullet$ & $\bullet$ & & & $\bullet$ \\
\hline
\end{tabular}




\begin{tabular}{|l|l|l|l|l|l|l|}
\hline 13. & AI6 & & $\bullet$ & $\bullet$ & & $\bullet$ \\
\hline 14. & AI7 & $\bullet$ & $\bullet$ & $\bullet$ & & $\bullet$ \\
\hline 15. & DS1 & $\bullet$ & $\bullet$ & $\bullet$ & & \\
\hline 16. & DS2 & $\bullet$ & $\bullet$ & $\bullet$ & & $\bullet$ \\
\hline 17. & DS3 & & $\bullet$ & $\bullet$ & $\bullet$ & $\bullet$ \\
\hline 18. & DS4 & $\bullet$ & $\bullet$ & $\bullet$ & $\bullet$ & $\bullet$ \\
\hline 19. & DS5 & $\bullet$ & $\bullet$ & $\bullet$ & $\bullet$ & $\bullet$ \\
\hline 20. & DS6 & $\bullet$ & & & & \\
\hline 21. & DS7 & $\bullet$ & & & & \\
\hline 22. & DS8 & $\bullet$ & $\bullet$ & $\bullet$ & $\bullet$ & $\bullet$ \\
\hline 23. & DS10 & $\bullet$ & $\bullet$ & $\bullet$ & $\bullet$ & $\bullet$ \\
\hline 24. & DS11 & $\bullet$ & $\bullet$ & $\bullet$ & $\bullet$ & $\bullet$ \\
\hline 25. & DS12 & & $\bullet$ & & & \\
\hline 26. & DS13 & & $\bullet$ & & & \\
\hline 27. & ME1 & $\bullet$ & $\bullet$ & $\bullet$ & $\bullet$ & $\bullet$ \\
\hline 28. & ME2 & $\bullet$ & $\bullet$ & $\bullet$ & $\bullet$ & $\bullet$ \\
\hline 29. & ME4 & $\bullet$ & & & & \\
\hline
\end{tabular}

\section{E. Pembahasan Maturity Level}

Berdasarkan hasil wawancara dengan narasumber, didapatkan ukuran tingkat kematangan Fakultas Teknik dalam menerapkan tata kelola teknologi informasi yang berdasarkan kerangka kerja COBIT 4.1. Hasil penilaian tingkat kematangan tersebut disajikan pada tabel berikut ini:

Tabel 6. Daftar hasil tingkat kematangan proses TI

\begin{tabular}{|c|c|c|}
\hline No. & Proses & Tingkat Kematangan \\
\hline 1 & $\mathrm{PO} 2$ & 2,80 \\
\hline 2 & PO3 & 2,83 \\
\hline 3 & PO4 & 2,67 \\
\hline 4 & PO5 & 2,50 \\
\hline 5 & PO6 & 1,00 \\
\hline 6 & PO7 & 2,40 \\
\hline 7 & PO8 & 1,00 \\
\hline 8 & PO10 & 2,50 \\
\hline 9 & AI2 & 2,50 \\
\hline 10 & $\mathrm{AI} 3$ & 2,17 \\
\hline 11 & AI4 & 2,50 \\
\hline 12 & AI5 & 3,00 \\
\hline 13 & AI6 & 2,67 \\
\hline 14 & AI7 & 1,25 \\
\hline 15 & DS1 & 1,17 \\
\hline 16 & DS2 & 2,75 \\
\hline 17 & DS3 & 2,38 \\
\hline 18 & DS4 & 2,40 \\
\hline 19 & DS5 & 2,16 \\
\hline 20 & DS6 & 2,50 \\
\hline 21 & DS7 & 3,50 \\
\hline 22 & DS8 & 2,30 \\
\hline 23 & DS10 & 2,30 \\
\hline 24 & DS11 & 2,50 \\
\hline 25 & DS12 & 2,50 \\
\hline 26 & DS13 & 2,50 \\
\hline 27 & ME1 & 1,50 \\
\hline
\end{tabular}

\begin{tabular}{|c|l|l|}
\hline 28 & ME2 & 1,60 \\
\hline 29 & ME4 & 1,00 \\
\hline \multicolumn{2}{|c|}{ Rata-rata } & 2,08 \\
\hline
\end{tabular}

Dari 29 proses diatas, dapat dikatagorikan menjadi tiga tingkat kematangan. Tingkat 1 initial/ad hoc dengan rentang nilai $>0,5$ sampai dengan 1,5 . Tingkat 2 repeatable but intuitive dengan rentang nilai $>1,5$ sampai dengan 2,5. Tingkat 3 defined dengan rentang nilai $>2,5$ sampai dengan 3,5 . Proses yang berada pada tingkat 1 berjumlah enam proses, proses yang berada pada tingkat 2 sebanyak enam belas proses dan proses yang berada pada tingkat 3 berjumlah tujuh proses.

Berdasarkan perhitungan tingkat kematangan diatas, dapat diketahui bahwa nilai rata-rata yang merupakan kondisi as-is tingkat kematangan Fakultas Teknik secara keseluruhan berada pada level 2 repeatable but intuitive, artinya dalam proses-proses TI yang berjalan telah terdapat prosedur serupa yang diikuti oleh orang berbeda yang melakukan tugas yang sama. Kurangnya pelatihan atau komunikasi formal tentang prosedur standar, serta tanggung jawab diserahkan kepada individu masing-masing. Terdapat suatu ketergantungan yang tinggi terhadap pengetahuan/ keahlian dari individu, oleh karena itu kesalahan masih sering terjadi.

\section{KESIMPULAN DAN SARAN}

Pada bagian ini akan dijelaskan kesimpulan dan saran dari hasil penelitian dan pembahasan.

\section{A. Kesimpulan}

Berdasarkan hasil penelitian dan pembahasan, maka dapat diambil kesimpulan sebagai berikut :

1) Berdasarkan mapping antara tujuan bisnis Fakultas Teknik dan tujuan bisnis yang disediakan COBIT 4.1, didapat dua puluh sembilan proses yang layak untuk dilakukan audit tata kelola TI, masing-masing delapan proses dari domain Plan and Organise (PO), enam proses dari domain Acquire and Implement (AI), dua belas proses dari domain Deliver and Support (DS) dan tiga proses dari domain Monitor and Evaluate (ME).

2) Berdasarkan analisis tata kelola TI di Fakultas Teknik, didapat tiga proses yang yang memiliki tingkat kematangan terendah, yakni proses PO6 Communicate management aims and direction, PO8 Manage quality dan ME4 Provide IT governance, dengan nilai kematangan 1 dan berada pada tingkat initial / ad-hoc, dimana kondisinya tidak ada proses yang baku, sebagai gantinya ada pendekatan khusus yang cenderung diterapkan per kasus. Pendekatan manajemen secara keseluruhan belum terorganisasi.

3) Berdasarkan analisis tata kelola TI, proses yang memiliki tingkat kematangan tertinggi adalah proses DS7 Educate and train users dengan nilai kematangan 3,50 berada pada tingkat defined, dimana kondisi prosedur telah baku dan telah didokumentasikan, namun masih belum terdapat pengukuran dan monitoring terhadap hasil dari proses ini.

4) Secara keseluruhan kondisi kematangan tata kelola Teknologi Informasi di Fakultas Teknik menurut kerangka kerja COBIT 4.1 berada pada level 2 yakni 
repeatable but intuitive. Dimana hal ini berarti proses telah berkembang pada tahap dimana prosedur serupa diikuti oleh orang berbeda yang melakukan tugas yang sama. Namun belum ada pelatihan dan komunikasi formal dari prosedur standar, dan tanggung jawab masih diserahkan kepada individu. Tabel berikut menunjukkan hasil analisis tingkat kematangan dari setiap domain dalam COBIT 4.1.

Tabel 7. Tingkat kematangan tata kelola TI di FT UNDIP

\begin{tabular}{|c|c|}
\hline Domain & Tingkat Kematangan \\
\hline PO (Plan and Organize $)$ & 2,21 \\
\hline DS (Deliver and Support $)$ & 2,35 \\
\hline AI (Acquire and Implement) & 2,41 \\
\hline ME (Monitor and Evaluate) & 1,37 \\
\hline Rata-rata & 2,08 \\
\hline
\end{tabular}

5) Berdasarkan analisis tata kelola TI di Fakultas Teknik secara keseluruhan, didapat beberapa kelemahan dalam proses TI yang berjalan, diantaranya penetapan dan dokumentasi tindakan, kebijakan dan prosedur yang minim. Tidak tersedianya service level yang disetujui bersama, minimnya manajemen mutu dengan tidak adanya fungsi monitoring pada setiap proses TI. Dan minimnya evaluasi terhadap performansi TI serta tidak adanya pelaporan resmi dalam keberjalanan proses TI.

\section{B. Saran}

Terdapat beberapa saran dari hasil penelitian yaitu sebagai berikut :

1) Untuk proses pemetaan (mapping), dapat menggunakan assessment tools dari COBIT yang bersifat otomatis dan lebih sesuai dengan COBIT.
2) Pertanyaan yang digunakan dalam wawancara dapat disederhakan sehingga tidak terlalu banyak atau bisa menggunakan jenis pertanyaan atau wawancara dengan format yang lebih sederhana, misalnya seperti menggunakan assessment tools yang disediakan oleh COBIT.

\section{DAFTAR PUSTAKA}

[1] Basrowi dan Suwandi. 2008. Memahami Penelitian Kualitatif. Jakarta: Rineka Cipta.

[2] Fakultas Teknik. 2010. Rencana Strategis Fakultas Teknik Undip 2010-2015.

[3] Fakultas Teknik. 2013. Pedoman Fakultas Teknik.

[4] Gondodiyoto, Sanyoto. 2007. Audit Sistem Informasi + Pendekatan COBIT. Jakarta: Mitra Wacana Media.

[5] IT Governance Institute (ITGI). 2000. COBIT Audit Guidelines. Rolling Meadow. USA

[6] IT Governance Institute (ITGI). 2007. COBIT 4.1: Framework, Control Objectives, Management Guidelines, Maturity Models. Rolling Meadow. USA

[7] Kesumawardhani, Dwi Rizki. 2012. Evaluasi It Governance Berdasarkan Cobit 4.1 (Studi Kasus Di Pt Timah (Persero) Tbk). Skripsi Fakultas Ekonomi Universitas Indonesia.

[8] Ramadhanty, Dwiani. 2010. Penerapan Tata Kelola Teknologi Informasi Dengan Menggunakan Cobit Framework 4.1 (Studi Kasus Pada Pt. Indonesia Power). Tesis Fakultas Ekonomi Universitas Indonesia.

[9] Silvana, Lusia dan Asnur, Ivanna. 2007. Analisa Pengelolaan Teknologi Informasi dengan Framework COBIT 4.0 di PT Coca Cola Bottling Indonesia Jawa Timur. Skripsi Fakultas Teknik Universitas Kristen Petra.

[10] Tata Kelola TI, 16 Juli 2013. http://id.wikipedia.org/wiki/IT Governance/

\section{BIODATA}

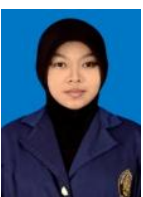

Arini Arumana, lahir di Grobogan 14 September 1991. Pendidikan yang telah ditempuh yaitu TK Pertiwi 1, SDN 3 Baturagung, SMPN 3 Gubug, dan SMAN 1 Gubug. Sekarang sedang menyelesaikan pendidikan Strata Satu di Program Studi Sistem Komputer, Universitas Diponegoro, Semarang, Indonesia Angkatan Tahun 2009. 